\title{
Examining the Impact of Novel Pre-activity Tasks on Macroskills: The Case of Group Discussion on Writing Ability
}

\author{
Hooshang Khoshsima \\ Department of English Language, Chabahar Maritime University, Chabahar, Iran \\ E-mail: Khoshsima2002@yahoo.com \\ Esmail Zare-Behtash \\ Department of English Language, Chabahar Maritime University, Chabahar, Iran \\ E-mail: behtash@cmu.ac.ir \\ Mahboobeh Khosravani (Corresponding author) \\ Department of English Language, Chabahar Maritime University, Chabahar, Iran \\ E-mail: Khosravani7@gmail.com
}

Doi:10.7575/aiac.alls.v.7n.1p.148

URL: http://dx.doi.org/10.7575/aiac.alls.v.7n.1p.148
Received: 11/09/2015

Accepted: 16/11/2015

\begin{abstract}
The main concern of most researchers in the field of second and foreign language teaching is lessening the problems and eliminating the hinders on the way of learning a language. Writing is considered as one of the most challenging and complicated tasks for learners to perform particularly when they have to write in a second or foreign language. Numerous studies were done on the importance of the pre-writing stage and activities which are directly and indirectly related to the theme of the writing. Accordingly, the main aim of this study was to examine the effects of group discussion as a pre- activity task on writing ability. To this aim, 27 Iranian EFL learners, who were at the same level intermediate- studying at Shokuh and Safir Institutes, Birjand, Iran were chosen randomly. Two groups- one control and one experimental group- were studied. In control group the conventional method was used in teaching writing, while in experimental group, group discussion pre-activity task was administered. After 16 sessions, the obtained data of the pretests and posttests was analyzed by SPSS software. According to the results, researcher strongly concluded that group discussion has no significant effect on writing ability of Iranian intermediate learners. This study can help teachers and syllabus designers in choosing and applying an effective pre-activity task.
\end{abstract}

Keywords: writing ability, pre-activity task, group discussion, EFL learners

\section{Introduction}

Writing is considered as one of the most challenging and complicated tasks for learners to perform particularly when they have to write in a second or foreign language. All of us may experience it when we start to write about something, we face a lot of difficulties especially in the very beginning. In another words, writing is not only to put our pen on paper and place the words in their right place. In fact, writing is difficult for students as it demands other linguistic, cognitive and metacognitive strategies to be used (Rao, 2007). Furthermore, Pishghadam and Ghanizadeh (2006) proposed that although students pass several years in writing classes, still they have a lot of problems in the process of writing.

On the other hand, the importance and necessity of writing skill is clear for all teachers and researchers as it enables them to think critically, organize their opinions, and finally to compose what they have in their mind. Rao (2007) indicated the importance of writing in this way,

"Writing has always been regarded as an important skill in the teaching and learning English as a Foreign Language (EFL). On the one hand, it stimulates thinking, compels students to concentrate and organize their ideas, and cultivates their ability to summarize, analyze, and criticize. On the other hand, it reinforces learning in, thinking in, and reflecting on the English language" (p.100).

It is believed that most students have difficulty in the very beginning of writing (Mousapour negari, 2011). All the time, students express their complaints that they cannot organize their thoughts and write about something engrossing and relevant to the topic. Although teachers are aware of these problems, they cannot find suitable techniques to eliminate students' obstacles in the processes of writing (Rao, 2007). Before starting to write, as Pishghadam and Ghanizadeh (2006) suggested, students need more preparations and exercises to overcome the difficulties of writing. As a result, teachers should pay more attention on prewriting stage. Recently, a large number of studies are done to examine the effects of prewriting tasks on writing ability. The term 'pre-writing' has two different meanings. It can mean the stage 
before children learn writing, which is referred to as hand skills. The other meaning, which is the concern of this study, relates to a pre-activity like group discussion.

Using group discussion is a pre- activity task which is known as collaborative learning, cooperative learning, peer learning, group learning, formal learning groups, and study teams (Johnson, Johnson, \& Smith, 1991). Using group discussion as a pre- activity task means setting up some cooperative groups of students in class and asking them to discuss a specific topic with each other. Johnson and Johnson and Holubec (1998) defined a cooperative group as "a group whose members are committed to a common purpose of maximizing each other's learning" (p.72).

\section{Review of Literature}

\subsection{Writing Skill}

According to Chastain (1988) "Writing is a basic communication skill and a unique asset in the process of learning a second language. Producing a successful written text is a task which requires simultaneous control over a number of language systems.” (p. 244) Many scholars believe that teaching writing should be in a way that stimulates student output and only then should generate teacher response and conferencing (e.g Reid, 1993).

According to Widdowson (1983), writing is an interactive process of negotiation. However, providing a coherent and cohesive piece of writing is difficult since, as Zamel (1987) states, writing has a complex, recursive and non-linear nature requiring a variety of micro-skills. This might be a reason why there is no agreement among second language scholars over the best approach to teach or learn it.

A considerable body of literature on L2 writing (e.g. Kern \& Schultz, 1992; East, 2008; Zamel, 1987) challenges the product approach and, instead, focuses on the process-oriented view. Based on Zamel (1983), researchers have found that the investigation of students' written products do not demonstrate much about their instructional needs. That is why they are now exploring writing behaviors, which can offer insight into how to teach it. In this view, what is required is the implementation of a supportive environment in which L2 learners are encouraged to take risk and get engaged in creating meaning.

In addition, the negotiation on assessment practice is indicative of the conflict between two main approaches towards writing. According to East (2008), "one view is influenced by knowledge-based approaches that favor the static assessment of writing. The advocates of this view use tests that produce a snapshot of the L2 test takers' writing ability and measure knowledge of key components. They emphasize the discriminatory power of the test to predict future success. The other view is affected by the process-oriented approach that focuses on dynamic assessment, which is more learner-centered. Based on this view, the proficiency construct of communicative writing is as an authentic reflection of writing as process." (p. 37)

\subsection{Pre-writing Activities}

Starting writing is a problem for many, especially young writers. Tompkins (2001) points out that the most neglected stage is the pre-writing stage. Blackburn-Brockman (2001) signalizes that many pre-service teacher education students in a composition methods course confess they did not prewrite seriously in middle and high school, and that many did not pre-write at all. However, it is an important phase in the writing process frequently overlooked by beginning writers. Thorne (1993) indicates that prewriting is the most important skill to emphasize and practice extensively in basic writing classes. She describes basic writers as almost universally neglecting prewriting activities. She suggests some guidelines for teaching prewriting effectively.

The term 'pre-writing' has two different meanings. It can mean the stage before children learn writing, which is referred to as hand skills. The other meaning, which is the concern of this study, relates to pre-activities like pre-questioning, using visual aids, and group discussion.

As the researcher believes, the schema theory which was explained in details in the pre-writing part of this chapter is also directly related to pre-writing activities as well. This claim is mentioned because the ultimate goal of using prewriting activities is activating or developing students' background knowledge to write more successfully. Therefore, the researcher refers you to the information presented in the pre-reading part of this chapter and does not replicate those aforementioned ideas on schema theory, background knowledge and so on.

\subsection{Group Discussion}

Cooperative learning is one strategy for group instruction which is under the learner-centered approach. Therefore, some of the definitions, perceptions, and studies done in this area are presented in this part as well. To begin, it is worth mentioning that many educators express different the definitions of cooperative learning. For example, Slavin (1995) defines cooperative learning as "an instructional program in which students work in small groups to help one another master academic content." Brown (1994) says that "Cooperative learning involves students working together in pairs or groups, and they share information . They are a team whose players must work together in order to achieve goals successfully." In addition, Kessler (1992) proposes the definition of cooperative learning particularly in language learning context. He mentions that "Cooperative learning is a within-class grouping of students usually of differing levels of second/foreign language proficiency, who learn to work together on specific tasks or projects in such a way that all students in the group benefit from the interactive experience."

According to Johnson (2005), cooperation is not assigning an activity to a group of students where one student does all the work and the others put their names on the paper. On the contrary, cooperative learning is a teaching strategy in 
which small groups, which have members with different level, use a variety of learning activities to enhance their understanding of the lesson. Furthermore, Richards \& Rodgers (2001) indicated that "a central premise of CLL (Cooperative Language Learning) is that learners develop communicative competence in a language by conversing in socially or pedagogically structured situations" (p.194)

In addition, Nuttal (1982) also claims that discussion promotes the active struggle with the text and students learn the processes of critical thinking that good readers use. Group work is ideal, because in small groups, even the weaker students should be active and attend the teaching and learning process. The procedure works in almost every level, and discussion can be in their mother tongue, if students cannot manage it in the foreign language.

Some of the scholars and researchers suggest different techniques and guidelines for better performing of groupdiscussion activity. For instance, some of them (Emdin, 2010; Larson, 2000; Mitchell, 2010) believe that classroom discussions must be practiced at the beginning of each school year so students will have a clear understanding of what is expected of them. They also add that the teacher must set the discussion expectations, and the students must understand that they are responsible for their own learning. Also, teachers must provide ownership to each learner's comment after he or she has spoken. They also mention that the teacher should build a classroom environment in which all are equal participants.

Some others (Larson, 2000; Mitchell, 2010) state that students must feel a high level of comfort before being able to communicate their views about a topic with their peers. They also suggest a solution. They say that the best way to facilitate this level of confidence is to allow students time to work in cooperative learning groups before having to speak in front of an entire room of their classmates. Teachers may supervise and observe these first few meetings before actively engaging as a participant in the discussions with the students. Once students are more comfortable with the discussion format, a whole group discussion can ensue which may give them the confidence to share different points of view.

Considering all aforementioned definitions, views, and studies done on writing skill, pre-activity tasks, and group discussion, research questions, study method, results, conclusion, etc. are mentioned in the following parts.

\subsection{Research Question and Hypothesis}

RQ. Does group discussion strategy as a pre- activity task have a significant effect on writing ability of Iranian intermediate EFL learners?

H0. Group discussion strategy as a pre- activity task has no significant effect on writing ability of Iranian intermediate EFL learners.

\section{Method}

\subsection{Participants}

The participants of this study are 27 Iranian EFL learners, who are at the same level -intermediate- studying at Shokuh and Safir Institutes, Birjand, Iran. Their age range is among 16 to 25 . Both male and female students were entered to this study. These participants were in two classes- 13 participants in the control group and 14 participants in group discussion group. The specifications of these 27 participants are given in table 1 .

Table 1. Participants' Specifications

\begin{tabular}{llll}
\hline & & Number & Percent \\
\hline \multirow{2}{*}{ Gender } & Male & 10 & $35 \%$ \\
& Female & 17 & $65 \%$ \\
\hline \multirow{2}{*}{ Age } & $16-20$ & 16 & $58 \%$ \\
& $20-25$ & 11 & $42 \%$ \\
\hline
\end{tabular}

\subsection{Instruments and Materials}

In this part all instruments and materials which were used for conducting this research will be mentioned. The materials and instruments which used for carrying on this study are as follow.

\subsubsection{TOEFL Tests}

TOEFL test (Test of English as a Foreign Language) is one of the most acceptable and well-known tests all over world. Nowadays, most researchers use TOEFL tests to obtain their required data as there is no doubt about their validity and reliability. TOEFL tests are in two formats: PBT (Paper-based Test) and iBT (Internet-based Test). Although iBT innovated in late 2005, it could replace progressively PBT and CBT (Computer-based Test). By the way, PBT is still in use in some regions. TOEFL test integrates all four skills -reading, writing, speaking, and listening- to measure the overall skill of communicating in foreign language. In details, in a TOEFL test, the testee is subject to a reading test and has to read a text and answer a number of questions, a writing test and has to write properly about a certain topic, a listening test and has to listen to conversations and answer questions, and finally a speaking test and has to speak about a certain topic. 
In this study, the researcher preferred to use a Paper-Based version of TOEFL taken from Longman Preparation Course for the TOEFL Test (the Paper Based Test) (Phillips, 2005). As only intermediate students are involve in this study, at first, the researcher administered a TOEFL proficiency test to all participants to ensure that all of them met the intermediate level. Then, one TOEFL writing ability test was used at the outset of the study as the pre-test in both groups. This pre-test was also used to check the homogeneity of the participants and to ensure that their writing ability was also at the same level. Additionally, one TOEFL writing test was administered in these two groups at the end of treatment as the post-test. The readability scale was used to make sure that the tests are at the same level.

\subsubsection{SPSS (Statistical Package for the Social Science) Software}

SPSS software is worldwide software which is used for statistical analysis to a great degree. All essential statistical analysis of this study was done by use of $20^{\text {th }}$ version of SPSS software. The data collected from TOEFL tests were analyzed by SPSS software.

\subsection{Procedures}

In this study, two groups- one control and one experimental group- were studied. In control group the conventional method was used, while in experimental group, group discussion pre-activity task was administered. Both groups met the same level -Intermediate. In each session, writing was taught based on this specific pre- activity task. In the first session, before performing any treatment, one pre-test of writing was administered in each group. Then, the treatments were conducted in 16 sessions. The levels of all tests were checked by readability scale which revealed that all tests were at the same level of difficulty. A TOEFL proficiency test was used to check the homogeneity of the participants. After that, the process of teaching was started and this pre- activity task was applied in the experimental group. In the last session, a writing ability test was administered in each of those two groups. The writing tests were corrected by two teachers. At the end, the obtained data of the tests was analyzed by SPSS software which are revealed in the next part.

\section{Results}

The purpose of this section is to answer the research question which is "Does group discussion strategy as a pre- activity task have a significant effect on writing ability of Iranian intermediate EFL learners?". To meet this aim, at first one independent sample t-test was employed to examine the homogeneity of groups.

Table 2. Group Statistics

\begin{tabular}{|c|c|c|c|c|c|}
\hline & Pretest & $\mathrm{N}$ & Mean & Std. Deviation & Std. Error Mean \\
\hline \multirow{2}{*}{ pretest writing scores } & pretest group discussion group & 14 & 7.5000 & 1.12233 & .29995 \\
\hline & pretest control group & 13 & 6.5577 & 1.40740 & .39034 \\
\hline
\end{tabular}

As displayed in table 2, mean score and standard deviation for discussion group are 7.5 and 1.1, respectively. On the other hand, mean score and standard deviations for control group are 6.5 and 1.4. As a result, these groups were similar and homogenous at the outset of the study. Next table tries to prove the same reality by use of inferential statistics.

Table 3. Independent Samples Test

\begin{tabular}{|c|c|c|c|c|c|c|c|c|c|c|}
\hline & & \multicolumn{2}{|c|}{$\begin{array}{l}\text { Levene's Test } \\
\text { for Equality of } \\
\text { Variances } \\
\end{array}$} & \multicolumn{7}{|c|}{ t-test for Equality of Means } \\
\hline & & \multirow[t]{2}{*}{$\mathrm{F}$} & \multirow[t]{2}{*}{ Sig. } & \multirow[t]{2}{*}{$\mathrm{t}$} & \multirow[t]{2}{*}{ df } & \multirow[t]{2}{*}{$\begin{array}{l}\text { Sig. (2- } \\
\text { tailed) }\end{array}$} & \multirow[t]{2}{*}{$\begin{array}{l}\text { Mean } \\
\text { Difference }\end{array}$} & \multirow[t]{2}{*}{$\begin{array}{l}\text { Std. Error } \\
\text { Difference }\end{array}$} & \multicolumn{2}{|c|}{$\begin{array}{l}\text { 95\% Confidence } \\
\text { Interval of the } \\
\text { Difference }\end{array}$} \\
\hline & & & & & & & & & Lower & Upper \\
\hline \multirow{2}{*}{$\begin{array}{l}\text { Pretest } \\
\text { writing } \\
\text { scores }\end{array}$} & $\begin{array}{l}\text { Equal } \\
\text { variances } \\
\text { assumed }\end{array}$ & .870 & .360 & 1.931 & 25 & .065 & .94231 & .48808 & -.06290 & 1.94752 \\
\hline & $\begin{array}{l}\text { Equal } \\
\text { variances } \\
\text { not assumed }\end{array}$ & & & 1.914 & 22.965 & .068 & .94231 & .49228 & -.07614 & 1.96075 \\
\hline
\end{tabular}

As illustrated in table 3, significant value is .065 >.05; so these two groups were not different before starting the treatment and they were homogenous. The next table tries to compare the posttests of experimental and control groups to answer research question. 


\begin{tabular}{llllll}
\hline & Posttest & $\mathrm{N}$ & Mean & Std. Deviation & Std. Error Mean \\
\hline \multirow{2}{*}{ posttest writing scores } & $\begin{array}{l}\text { posttest group discussion } \\
\text { group }\end{array}$ & 14 & 7.4821 & 1.53003 & .40892 \\
& posttest control group & 13 & 6.6731 & 1.44476 & .40071 \\
\hline
\end{tabular}

Table 4 tries to compare groups by use of descriptive statistics. As mean score and standard deviation for discussion group are 7.4 and 1.5 and for control group are 6.6 and 1.4, it can be concluded that these groups are not significantly different as also shown in next table.

Table 5. Independent Samples Test

Levene's Test
for Equality of $\quad t$-test for Equality of Means
Variances

\begin{tabular}{|c|c|c|c|c|c|c|c|c|}
\hline \multirow[t]{2}{*}{$\mathrm{F}$} & \multirow[t]{2}{*}{ Sig. } & \multirow[t]{2}{*}{$\mathrm{t}$} & \multirow[t]{2}{*}{ Df } & \multirow[t]{2}{*}{$\begin{array}{l}\text { Sig. (2- } \\
\text { tailed) }\end{array}$} & \multirow[t]{2}{*}{$\begin{array}{l}\text { Mean } \\
\text { Difference }\end{array}$} & \multirow[t]{2}{*}{$\begin{array}{l}\text { Std. Error } \\
\text { Difference }\end{array}$} & \multicolumn{2}{|c|}{$\begin{array}{l}95 \% \text { Confidence } \\
\text { Interval of the } \\
\text { Difference }\end{array}$} \\
\hline & & & & & & & Lower & Upper \\
\hline \multirow[t]{2}{*}{.081} & .778 & 1.410 & 25 & .171 & .80907 & .57378 & -.37267 & 1.99080 \\
\hline & & 1.413 & 24.990 & .170 & .80907 & .57252 & -.37008 & 1.98822 \\
\hline
\end{tabular}

In table $5, \mathrm{df}=25, \mathrm{t}=1.4$, and significant value is .171 which is more than .05 . As a result, group discussion pre-activity does not affect significantly on writing ability. So the null hypothesis is accepted. In other words, group discussion as a pre-activity task has no significant effect on writing ability of Iranian intermediate EFL learners.

\subsection{Discussion}

Group discussion as a pre activity task has no significant effect on writing ability. As mentioned before, the unfulfilled effect of this pre-activity can be traced back in talking about other topics in groups or not participating appropriately in groups. The other reason for this failure is proposed by some researchers like Emdin, 2010; Larson, 2000; MarcumDietrich, 2010; Mitchell, 2010. They believe that classroom discussions must be practiced at the beginning of each school year so students will have a clear understanding of what is expected of them. They also add that the teacher must set the discussion expectations, and the students must understand that they are responsible for their own learning.

\section{Conclusion}

As discussed in chapters one and two of this study, the main concern of most researchers in the field of second and foreign language teaching is lessening the problems and eliminating the hinders on the way of learning a language. Consequently, many researchers have found out that using pre-activities in the process of teaching second/foreign languages is helpful. Therefore, the main aim of this study was to examine the effects of group discussion as a preactivity task on writing ability. According to the obtained data of the previous sections, it can be strongly concluded that group discussion has no significant effect on writing ability.

\section{References}

Blackburn-Brockman, E. (2001). Prewriting, Planning, and Professional Communication. English J, 91(2), 51-53.

Brown, H. (1994). Principles of language learning and teaching. New Jersey: Prentice Hall.

Chastain, K. (1988). Developing second language skills: Theory and practice (3rd ed.). Chicago: HBJ.

East, M. (2008). Dictionary use in foreign language writing exams: Impact and implications. International Journal of Lexicography, 22(3), 344-348.

Emdin, C. (2010). Dimensions of communication in urban science education: Interactions and transactions. Wiley Periodicals, Inc. doi: 10.1002/sce.20411

Johnson, D. (2005). Cooperative learning: increasing college faculty instructional productivity. Available Online at: www.ntlf.com/html/lib/bib/92-2dig.htm.

Johnson, D.W., Johnson, R.T., \& Smith, K.A. (1991). Active learning: Cooperation in the college classroom. Edina, $\mathrm{MN}$ : Interaction. 
Johnson, D. W., Johnson, R., \& Holubec, E. (1998). Advanced cooperative learning (2nd ed.). Edina, MN: Interaction Book.

Kessler, C. (1992). Cooperative language learning: A teacher resource book. Englewood Cliffs, NJ: Prentice Hall.

Larson, B. E. (2000). Classroom discussion: A method of instruction and a curriculum outcome. Teaching and Teacher Education, 16, 661-677.

Marcum-Dietrich, N. (2010). A scientist: Using science symposiums in the classroom. The Science Teacher, 77(4), 43.

Mitchell, I. (2010). The relationship between teacher behaviours and student talk in promoting quality learning in science classrooms. Research in Science Education, 40(2), 171-186.

Mousapour Negari, G. (2011). A Study on Strategy Instruction and EFL Learners' Writing Skill. International Journal of English Linguistics, 1(2), 299-307. doi:10.5539/ijel.v1n2p299

Nuttal, C. (1982). Teaching reading skills in a foreign language. Oxford: Macmilan Publishers.

Pishghadam, R., \& Ghanizadeh, A. (2006). On the Impact of Concept Mapping as a Prewriting Activity on EFL Learners' Writing Ability. IJAL Journal, 9(2).

Rao, Z. (2007). Training in Brainstorming and Developing Writing Skills. ELT Journal, 61(2), 100-106.

Reid, J. (1993). Teaching ESL Writing. Englewood Cliffs, NJ: Regents Prentice Hall.

Richards, J. C. \& Rodgers, T. S. (2001). Approaches and Methods in Language Teaching (2nd Ed.). Cambridge: Cambridge University Press.

Thorne, S. (1993). Prewriting: A basic skill for basic writers. Teaching English in the Two-Year College, 20(1), 31-36.

Tompkins, G. E. (2001). Literacy for the 21 st century: A balanced approach. Columbus, OH: Merrill Prentice Hall.

Widdowson, H. (1983). Learning purpose and language use. Oxford: Oxford University Press.

Zamel, V. (1983). The composing processes of advanced ESL students: Six cases studies. TESOL Quarterly, 17(2), 165-187.

Zamel, V. (1987). Recent research on writing pedagogy. TESOL Quarterly, 21(4), 697-715.

\section{Appendices}

\section{Appendix A (Writing Tests)}

\section{Writing Test 1}

Some people have the dream of traveling to Niagara Falls, while others don't care. What about you? Do you like to see Niagara Falls or not? Support your idea with reasons and examples (In about three paragraphs).

\section{Writing Test 2}

Some people have the dream of traveling to moon, while others don't care. What about you? Support your idea with reasons and examples (In about 3 paragraphs).

\section{Writing Test 3}

Nowadays youths prefer to wear jeans. What is your favorite style of trousers? Use specific reasons and examples to support your responses (In about 3 paragraphs).

\section{Writing Test 4}

What do you know about your brain? Write about different parts of brain and function in details (In about 3 paragraphs). 


\section{$1 \square 1 \square 1 \square 1 \square 1 \square 1 \square 1 \square 1$ COMPLETE TEST FIVE LISTENING COMPREHENSION \\ Time-approximately 35 minutes (including the reading of the directions for each part)}

In this section of the test, you will have an opportunity to demonstrate your ability to understand conversations and talks in English. There are three parts to this section, with special directions for each part. Answer all the questions on the basis of what is stated or implied by the speakers you hear. Do not take notes or write in your test book at any time. Do not turn the pages until you are told to do so.

\section{Part A}

Directions: In Part A you will hear short conversations between two people. After each conversation, you will hear a question about the conversation. The conversations and questions will not be repeated. After you hear a question, read the four possible answers in your test book and choose the best answer. Then, on your answer sheet, find the number of the question and fill in the space that corresponds to the letter of the answer you have chosen.

Listen to an example.

Sample Answer

On the recording, you will hear:

(man) That exam was just awful.

(woman) Oh, it could have been worse.

(narrator) What does the woman mean?

In your test book, you will read:

(A) The exam was really awful.

(B) It was the worst exam she had ever seen.

(C) It couldn't have been more difficult.

(D) It wasn't that hard.

You learn from the conversation that the man thought the exam was very difficult and that the woman disagreed with the man. The best answer to the question, "What does the woman mean?" is (D), "It wasn't that hard." Therefore, the correct choice is (D).

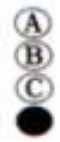




\section{$2 \cdot 2 \cdot 2 \cdot 2 \cdot 2 \cdot 2 \cdot 2 \cdot 2$ \\ SECTION 2 \\ STRUCTURE AND WRITTEN EXPRESSION \\ Time-25 minutes \\ (including the reading of the directions) \\ Now set your clock for 25 minutes.}

This section is designed to measure your ability to recognize language that is appropriate for standard written English. There are two types of questions in this section, with special directions for each type.

\section{Structure}

Directions: These questions are incomplete sentences. Beneath each sentence you will see four words or phrases, marked (A), (B), (C), and (D). Choose the one word or phrase that best completes the sentence. Then, on your answer sheet, find the number of the question and fill in the space that corresponds to the letter of the answer you have chosen.

Look at the following examples.

\section{Example I}

The president the election by a landslide.
(A) won
(B) he won
(C) yesterday
(D) fortunately

The sentence should read, "The president won the election by a landslide." Therefore, you should choose answer (A).

\section{Example II}

When the conference?
(A) the doctor attended
(B) did the doctor attend
(C) the doctor will attend
(D) the doctor's attendance

Sample Answer

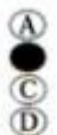

The sentence should read, "When did the doctor attend the conference?" Therefore, you should choose answer (B). 


\title{
$3 \triangle 3 \triangle 3 \triangle 3 \triangle 3 \triangle 3 \triangle 3 \triangle 3$
}

\author{
SECTION 3 \\ READING COMPREHENSION \\ Time- 55 minutes \\ (including the reading of the directions) \\ Now set your clock for 55 minutes.
}

This section is designed to measure your ability to read and understand short passages similar in topic and style to those that students are likely to encounter in North American universities and colleges. This section contains reading passages and questions about the passages.

Directions: In this section you will read several passages. Each one is followed by a number of questions about it. You are to choose the one best answer, (A), (B), (C), or (D), to each question. Then, on your answer sheet, find the number of the question and fill in the space that corresponds to the letter of the answer you have chosen.

Answer all questions about the information in a passage on the basis of what is stated or implied in that passage.

Read the following passage:

John Quincy Adams, who served as the sixth president of the United States from 1825 to 1829 , is today recognized for his masterful statesmanship and diplomacy. He dedicated his life to public service, both in the presidency and in the various other political offices that he Line held. Throughout his political career he demonstrated his unswerving belief in freedom of

(5) speech, the antislavery cause, and the right of Americans to be free from European and Asian domination.

\section{Example I}

Sample Answer

To what did John Quincy Adams devote his life?
(A) Improving his personal life
(B) Serving the public
(C) Increasing his fortune
(D) Working on his private business

According to the passage, John Quincy Adams "dedicated his life to public service." Therefore, you should choose answer (B).

\section{Example II}

In line 4, the word "unswerving" is closest in meaning to
(A) moveable
(B) insignificant
(C) unchanging
(D) diplomatic

The passage states that John Quincy Adams demonstrated his unswerving belief "throughout his career." This implies that the belief did not change. Therefore, you should choose answer (C). 